\title{
Feasibility Study of the Technical and Economic Performance of Grid-Connected PV System for Selected Rooftops in UTHM
}

\author{
Mohamad Fakrie Mohamad Ali ${ }^{1}$, Mohd Noor Abdullah ${ }^{2 *}$ \\ ${ }^{1}$ Faculty of Electrical and Electronic Engineering, \\ Universiti Tun Hussein Onn Malaysia, Batu Pahat, 86400, MALAYSIA \\ ${ }^{2}$ Green and Sustainable Energy Focus Group (GSEnergy), Faculty of Electrical and Electronics Engineering, \\ Universiti Tun Hussein Onn Malaysia, Batu Pahat, 86400, MALAYSIA \\ *Corresponding Author
}

DOI: https://doi.org/10.30880/jeva.2021.02.02.005

Received 11 July 2021; Accepted 17 October 2021; Available online 30 December 2021

\begin{abstract}
This paper presents the feasibility study of the technical and economic performances of grid-connected photovoltaic (PV) system for selected rooftops in Universiti Tun Hussein Onn Malaysia (UTHM). The analysis of the electricity consumption and electricity bill data of UTHM campus show that the monthly electricity usage in UTHM campus is very high and expensive. The main purpose of this project is to reduce the annual electricity consumption and electricity bill of UTHM with Net Energy Metering (NEM) scheme. Therefore, the gridconnected PV system has been proposed at Dewan Sultan Ibrahim (DSI), Tunku Tun Aminah Library (TTAL), Fakulti Kejuruteraan Awam dan Alam Bina (FKAAS) and F2 buildings UTHM by using three types of PV modules which are mono-crystalline silicon (Mono-Si), poly-crystalline silicon (Poly-Si) and Thin-film. These three PV modules were modeled, simulated and calculated using Helioscope software with the capacity of $2,166.40 \mathrm{kWp}, 2,046.20 \mathrm{kWp}$ and $1,845 \mathrm{kWp}$ respectively for the total rooftop area of 190,302.9 $\mathrm{ft}^{2}$. The economic analysis was conducted on the chosen three installed PV modules using RETScreen software. As a result, the Mono-Si showed the best PV module that can produce 2,332,327.40 kWh of PV energy, $4.4 \%$ of $\mathrm{CO}_{2}$ reduction, 9.3 years of payback period considering 21 years of the contractual period and profit of RM4,932,274.58 for 11.7 years after payback period. Moreover, the proposed installation of 2,166.40kWp (Mono-SI PV module) can reduce the annual electricity bill and $\mathrm{CO}_{2}$ emission of $3.6 \%(\mathrm{RM} 421,561.93)$ and $4.4 \%\left(1,851.40 \mathrm{tCO}_{2}\right)$ compared to the system without PV system.
\end{abstract}

Keywords: Helioscope, grid-connected photovoltaic, net energy metering, PV Modules, rooftops, RETScreen

\section{Introduction}

A Grid-Connected Photovoltaic (GCPV) system consists of an electricity-generating solar PV power system that is connected to the utility grid or also known as the power grid. The system is made up of several parts namely solar panels, one or several inverters, a power conditioning unit, and grid-connected equipment. Globally, it has become an attractive alternative to the government for power infrastructure expansion to take advantage of the increasing technological advancement and decreasing costs of PV systems [1]. Billing mechanisms such as Net Energy Metering (NEM) and Feed-in Tariff (FiT) which are offered by some system operators, can be used to offset a customer's electricity usage costs. 
Moreover, widely research on electric generation using renewable energy has been made to overcome the gas emission problem, increase in load demand, fluctuating oil prices, and gradual depletion of fossil fuels [2]. Renewable energy such as solar energy, wind energy, and hydropower energy promises to provide better electricity generation with less pollution and more environmentally friendly [2]. Solar energy which is produced by the sun is the easiest source that can be obtained at any place in this world compare to other renewable energy [3]. Energy generation from solar during the day time can provide significant carbon emission reduction based PV capacity. Therefore, carbon-negative can be achieved over the lifespan of GCPV which is any energy produced over and above that to install the panel initially offsets the need for burning fossil fuel.

Several studies have focused on the planning and designing of grid-connected systems consisting of PV without energy storage $[4,5,6]$. The potential of photovoltaic generation at UHTM was examined by [4] and concluded that the grid-connected PV system had reduced UTHM campus annual operating cost, annual grid purchased cost, carbon dioxide emission reduction, and annual electricity bill by using HOMER software. The technical and economic feasibility of a 50MW grid-connected solar PV at the UENR Nsoatre campus were also investigated by [5]. It was found that the costs of energy for the systems are lower than the set feed-in tariff which is based on the selected solar panels and Net Present Value (NPV) showed a positive value for all the systems with a reasonable payback period.

Feasibility analysis of the grid-connected and islanded operation of a solar PV microgrid system in Iraq was studied by [6]. The Homer software was used to analyze the techno-economic and environmental feasibility of a solar PV microgrid which able to supply the load during both grid availability and outage periods. They stated that implementing this kind of project could provide clean, economical, and continuous electricity production in countries with daily blackouts. The [7] discussed economic analysis of grid-connected residential rooftop PV systems in Turkey and Homer software used to identify the effect of varying feed-in tariff and PV initial cost on the feasibility of the systems. A comparative study of the feed-in tariff and net metering for UCSI University North Wing Campus with a $100 \mathrm{~kW}$ solar photovoltaic system was reported in [8]. MATLAB/Simulink was used to simulate the solar PV system for FiT, Net metering cost, and energy computation and concluded that FiT was more capable than NEM in terms of the monthly energy bill cost-saving and the return of investment as well [8]. The performance assessment of $3 \mathrm{~kW}$ gridconnected PV system in Korea was studied by [9] in terms of performance ratio, final yield, reference yield, and array yield for the selected solar panels.

Based on the literature review discussed above, this study aims to investigate the technical and economic performance of grid-connected PV system for designated rooftops in UTHM. The main purpose of this study is to ensure the UTHM annual electricity cost, annual electricity usage, and carbon dioxide emission can be reduced. Therefore, the average solar radiation in UTHM Batu Pahat is considered for designing the rooftop PV system. The grid-connected PV system is designed to analyze the technical and economic performance of the PV systems based on three different modules and the best-evaluated PV module which can reduce more of the electricity cost will be selected. The data analysis has been used in this project such as the annual load pattern of UTHM, solar radiation in UTHM campus, selection of suitable installation location of the PV system, design of grid-connected PV system, and simulation of PV system using Helioscope and RETScreen software.

\section{Methodology}

This section explains the methodology investigating the technical and economic feasibility of the solar PV system which is represented in Fig. 1. The initial phase starts with the pre-feasibility study providing an overview of the UTHM campus and establishing the campus's electricity consumption. The technical assessment of the project is also being performed as it involves the assessment of local resources such as the physical infrastructure and roof surface condition. The Helioscope software and Microsoft Excel were used as a tool to simulate the roof sizing as well the energy yield of the available solar resources.

The performance assessment phase covers module-specific information which comprises of the following: types of module, costs, efficiencies, and rooftop sizing requirements. Solar radiation data is combined with module-specific information for the energy model. The Helioscope software was used to examine an energy model for the assessment.

The economic analysis for this PV system project was conducted at the stage when the performance of the system is designed and analyzed based on the various PV system options. RETScreen and Microsoft excel were utilized to generate the financial aspects of the various PV systems. The outcome for each PV module was evaluated with the economic sustainability and cost efficiency factor. 


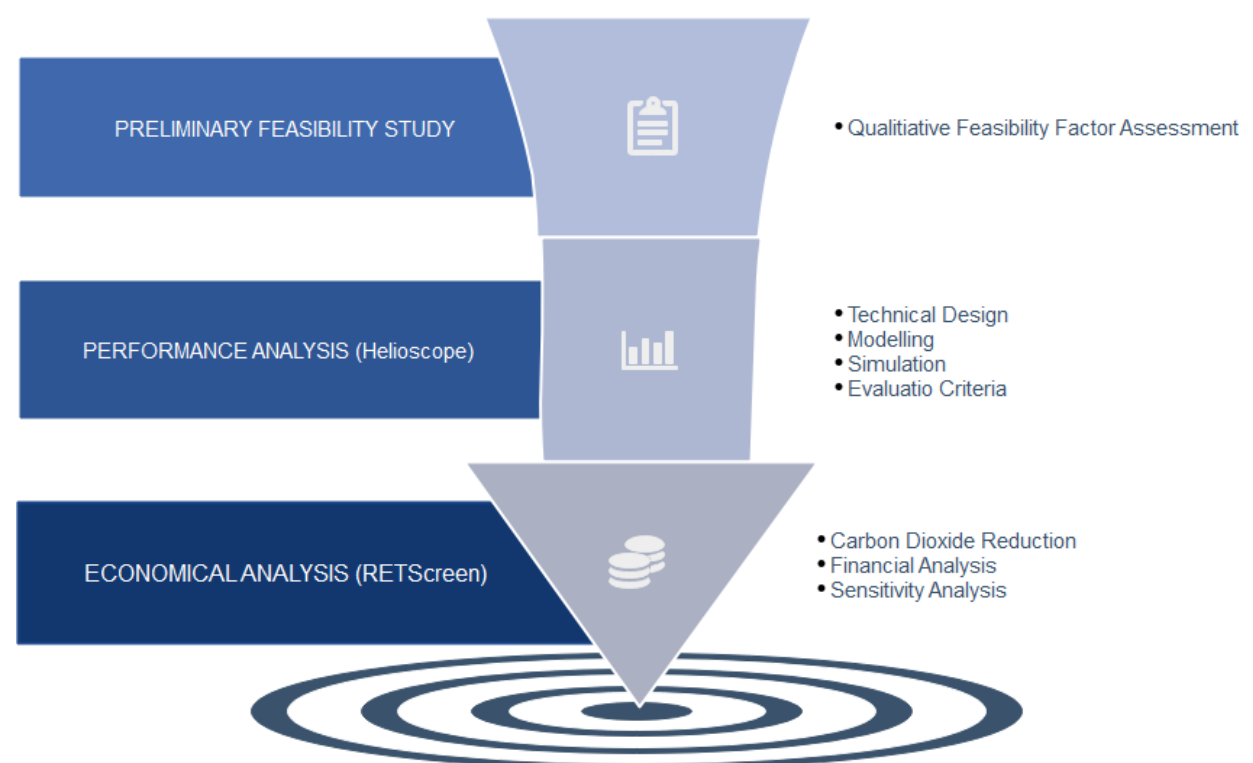

Fig. 1 - Flowchart of technical and economic evaluation criteria

\subsection{Design of GCPV System using Helioscope and RETScreen Software}

Helioscope is selected for this project to design, simulate and analyze the proposed PV system because it posses a combined comparative advantage. It provides tools that are capable of assessing technical details of the grid-connected PV system. Helioscope optimizes combinations of different microgrid system component sizes to meet the load demand of the case study site and provides tools to perform a wide range of calculations including detailed losses, energy production, performances, shading, etc. Moreover, RETScreen is also used due to various functionalities in integrating different functionalities in assessing projects and portfolio analysis. In addition, it is also capable to measure and verify the actual project performance [5].

\subsection{Description of UTHM Parit Raja Campus Building}

The study area of this project is focused on the main campus of Universiti Tun Hussein Onn Malaysia (UTHM) located in Batu Pahat District, Johor, Malaysia. Fig. 2 shows the maps of the UTHM extracted Google Maps. The coordinate of Universiti Tun Hussein Onn Malaysia (UTHM) in Google Map is $1^{\circ} 51^{\prime} 30.96^{\prime \prime}$ North and $103^{\circ} 5^{\prime} 8.16^{\prime \prime}$ East. UTHM campus consists of many buildings with facilities such as academic faculty, residential college, mosque, lecture hall, and library. The total population number in the UTHM campus is more than 10,000 people which consists of staff and students. The site is $21 \mathrm{~km}$ away from Batu Pahat district and $14 \mathrm{~km}$ from Ayer Hitam town [10].

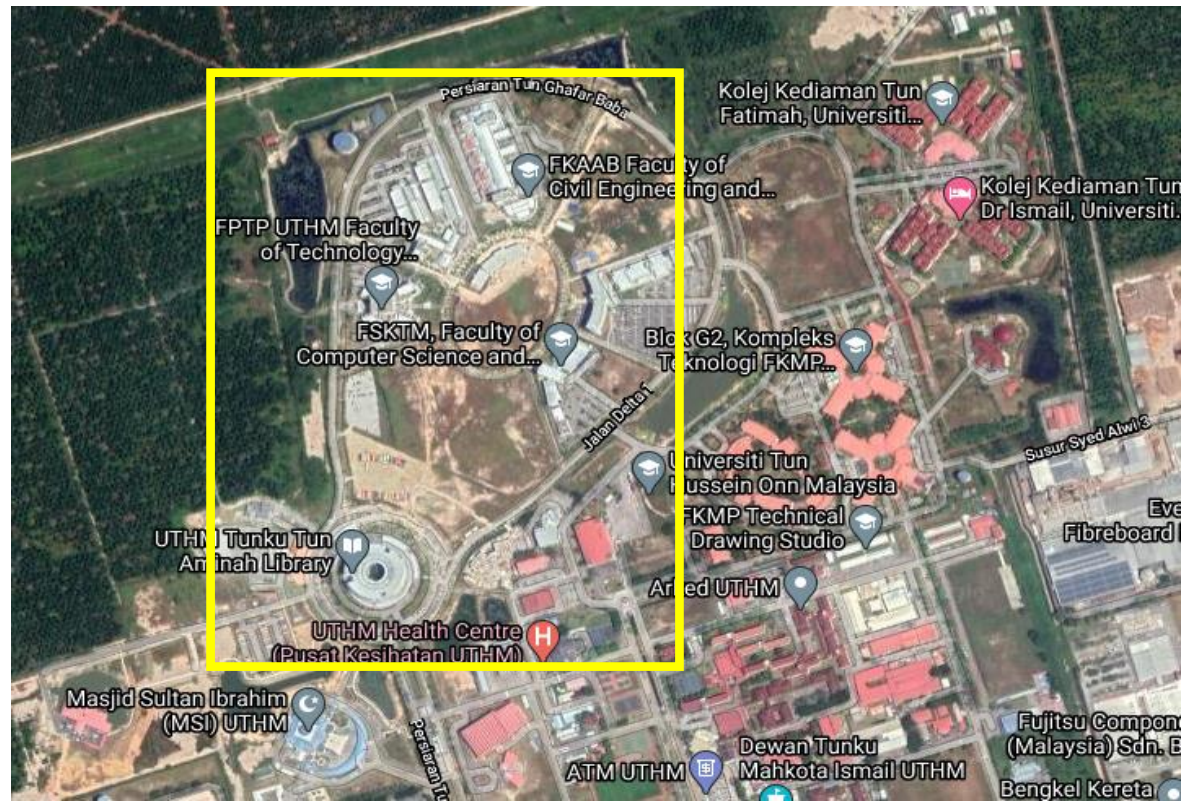

Fig. 2 - Location of the project site 


\subsection{Solar Radiation}

The monthly solar global radiation is obtained from the Surface Meteorology and Solar Energy (NASA-SSE) as shown in Fig. 3 [11]. The whole UTHM campus has experienced an average of $1663.4 \mathrm{kWh} /\left(\mathrm{m}^{2} . \mathrm{Yr}\right)$ solar irradiation in the year 2020. It also experiences monthly average irradiation from 4.07 to $5.22 \mathrm{kWh} /\left(\mathrm{m}^{2}\right.$. day) on a horizontal range surface and an average of $4.56 \mathrm{kWh} /\left(\mathrm{m}^{2}\right.$. day).

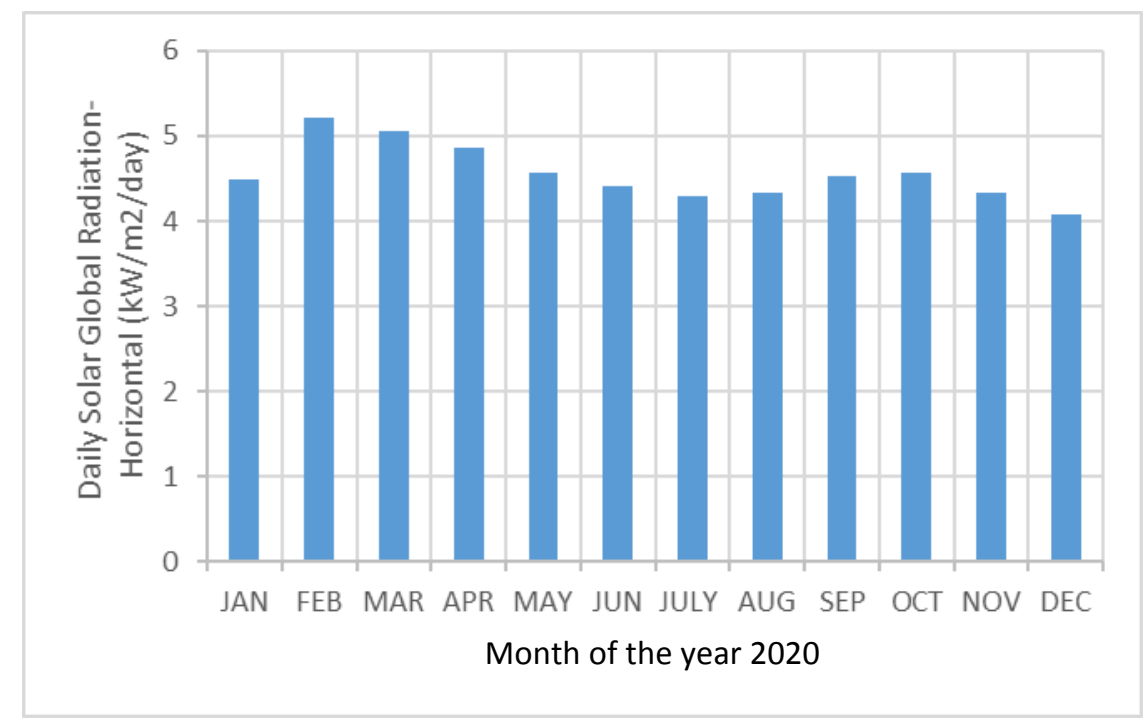

Fig. 3 - Monthly solar radiation (year 2020)

\subsection{Electricity Consumption Data of UTHM}

The baseline electricity consumption in 2018 and 2019 is chosen to evaluate the feasibility of the PV system in UTHM because of the movement control order (MCO) in 2020 and 2021. Fig. 4 presents the electricity consumption of 26,958,566 $\mathrm{kWh}$ and 26,406,713 $\mathrm{kWh}$ for 2018 and 2019 respectively. It can be seen that the higher electricity consumption occurs in March and October where most academic activities are conducted in these months. The academic calendar of UTHM consists of 2 semesters which are from January to May and from September to December. During the semester break (June to August), the consumption is slightly lower than other months.

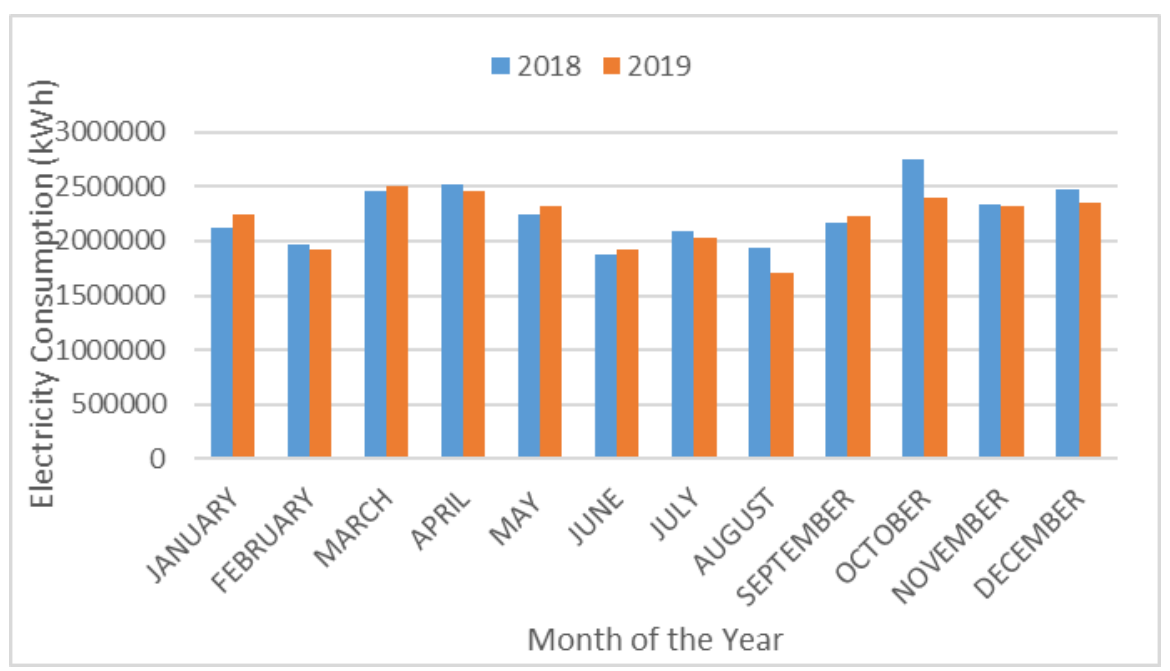

Fig. 4 - Monthly electricity consumption in the UTHM campus

\subsection{Technical Indicators of Solar PV System}

Indicator plants are used to calculate the project revenue which is based on the assessment of PV projects and to assess the stability of solar projects. The average annual energy output will be estimated for the proposed power plant which is typically 21-25 years. The overall performance of grid-tied PV systems is evaluated using these indicators and 
can be used to compare the performance of different PV configurations or systems [12]. The performance of the overall system is determined by the most common performance indicators reference to energy production, solar resource, and the overall effect of system losses to the final PV system yield, reference yield, performance ratio, capacitor factor, and special yield [12].

\subsubsection{Final PV System Yield $\left(Y_{f}\right)$}

$Y_{f}$ defines the total AC energy during a specific period direct proportional to the installation rate as shown in Eq. (1). Consequently, it is a significant parameter for the system performance comparison with other PV systems [13].

$$
Y_{f}=\frac{E}{P_{0}}
$$

where $Y_{f}$ as the final PV system yield, is calculated as the net energy output $E$ in $\mathrm{kWh}$ divided by the nameplate D.C. power, $P_{0}$ in $\mathrm{kW}$ of the installed PV array. $Y_{f}$ represents the number of hours that the PV array would require to generate at its rated power for the same energy and the unit can be expressed in hours.

\subsubsection{Reference Yield $\left(Y_{r}\right)$}

$Y_{r}$ determines the ratio of total in-plane solar radiation with the reference irradiance at standard test conditions (STC). It is a function of location, the orientation of PV array, and period time in month/annum weather variability as shown in Eq. (2).

$$
Y_{r}=\frac{H}{G}
$$

where $Y_{r}$ as the reference yield, is calculated as the total in-plane irradiance, $H$, divided by the PV's reference irradiance, $G$. It constitutes an equivalent number of hours for the reference irradiance. If substitute $G$ with $1 \mathrm{kWh} / \mathrm{m}^{2}$, then $H$ is the number of peak sun hours and the unit can be expressed in units of $\mathrm{kWh} / \mathrm{m}^{2}$ [5].

\subsubsection{Performance Ratio (PR)}

PR measures the performance of a PV system by taking into the environmental factors which are temperature, irradiation, climate changes, etc by using the following equation [14].

$$
P R=\frac{Y_{f}}{Y_{r}}
$$

\subsubsection{Specific Yield}

Specific yield is one of the most used performance metrics for solar systems. It is also used to compare different locations and analyze different designs [15]. The specific yield $(\mathrm{kWh} / \mathrm{kW})$ is the ratio of total annual energy generated $(\mathrm{kWh})$ to the installed capacity $(\mathrm{kWp})$ as given by Eq. (4).

$$
S_{f}=\frac{\text { Energy Generated per annum }(\mathrm{kWh})}{\text { Installed Capacity }(\mathrm{kWp})}
$$

\subsubsection{Capacity Factor (CF)}

CF defines resource availability both in terms of quantity and quality over a year of application [16]. the capacity factor $(\mathrm{CF})$ is simply the percentage of the ratio of energy generated per annum divided by $8760 \mathrm{hrs}$ times by the installed capacity of the PV module. CF is given in equations Eq. (5) and Eq. (6).

$$
\begin{gathered}
C F=\frac{\text { Energy Generated per annum }(k W h)}{8670(h / \text { year }) \times \text { Installed Capacity }(k W p)} \\
C F=\frac{S_{f}}{8760}
\end{gathered}
$$




\subsection{Economic Assessment Characteristics of PV System}

PV systems are generally characterized by the electricity cost charged by the utility and affordable operation cost. A discussion of key economic aspects for solar PV investments assessment is shown in 2.6.1, 2.6.2, and 2.6.3.

\subsubsection{Category Tariff of UTHM Campus}

The entire campus load profile is obtained from the main supply energy monitoring system which is Tenaga National Berhad (TNB). UTHM campus is registered under the commercial building C1 category which qualified the campus for Imbalance Cost Pass-Through (ICPT) rebate. Besides, there is also a renewable energy fund (KWTBB) collected to fund the FiT mechanism. In the $\mathrm{C} 1$ tariff category, the electricity supplied by TNB is sold at a fixed rate of RM $0.365 / \mathrm{kWh}$ for all [17]. The maximum demand (MD) charge is RM 30.30/kW. The Goods and Services Tax (GST) of $6 \%$ to be charged on the bill as shown in Table 1.

Table 1 - Energy rate of the grid system

\begin{tabular}{lc}
\hline Description & Rate $(\mathrm{RM})$ \\
\hline For each kilowatt of maximum demand per month & $30.30 / \mathrm{kW}$ \\
For all kWh (Peak Period) & $0.365 / \mathrm{kWh}$ \\
The minimum monthly charge & 600.00 \\
\hline
\end{tabular}

\subsubsection{Net Energy Metering (NEM)}

NEM is net energy after utilizing the PV system-generated energy. In general commercial such as UTHM campus, the load consumption period is from 9.00 A.M to 5.00 P.M during day time when sunlight is available for renewable energy generation through the PV system. The net metering system is considered suitable for the university campus that operates at this time hour because the Malaysia weather is considerably consistent throughout the whole year where the solar irradiance intensity peak between 12.00 P.M to 2.00 P.M, which falls between the peak demand period of the campus. The net energy consumption is defined in Eq. (7).

$$
N e t_{k W h}=k W h-R E_{k W h}
$$

where $k W h$ is the energy consumption and $R E_{k W h}$ is the generated renewable energy [1].

With the net metering scheme, the maximum demand power can be shaved off by the PV generated power as defined in equation Eq. (8) where $M D(T)$ is the peak power that occurred at a given time which can be identified from the load profile and $P V_{\text {out }}(T)$ is PV generated power at a given time when peak power occurred [18]. The net energy and maximum demand usage are defined in Eq. (9) and the total bill can be computed using Eq. (10).

$$
\begin{gathered}
M D_{\text {shaved }}=M D(T)-P V_{\text {out }}(T) \\
\text { Usage }=\left(\text { Net }_{k W h} \times \text { Energytariff }\right)+\left(M D_{\text {shaved }} \times \text { MDtariff }\right) \\
\text { Bill }=\text { Usage }+I C P T+K W T B B
\end{gathered}
$$

\subsubsection{Payback Period (PBP)}

The payback period for this project provides you with the duration to recover the initial cost of the setup. Upon completion of the installation, the savings obtained from the implementation as compared without the implementation contribute to that upfront investment [19]. Shorter payback time shows that the project is worth the effort in the economic aspect.

\section{Results and Discussion}


This section presented the result and discussion related to solar radiation and electricity consumption for the selected rooftops utilizing the chosen PV modules and inverters. The technical and economic performance have been analyzed based on the software simulation.

\subsection{The Selected Buildings}

A few buildings have been identified for the PV installation for this project. The selected buildings are Dewan Sultan Ibrahim (DSI), Examination Hall (F2), library, and Fakulti Kejuruteraan Awam dan Alam Bina (FKAAB) as shown in Fig. 5 given the large size of the rooftop which will be evaluated accordingly.

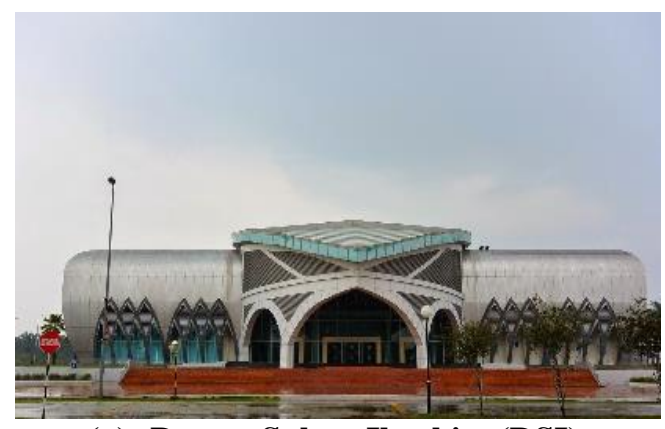

(a) Dewan Sultan Ibrahim (DSI)

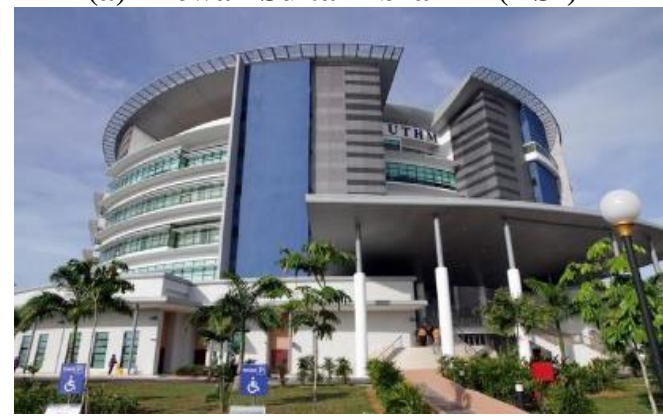

(c) Library

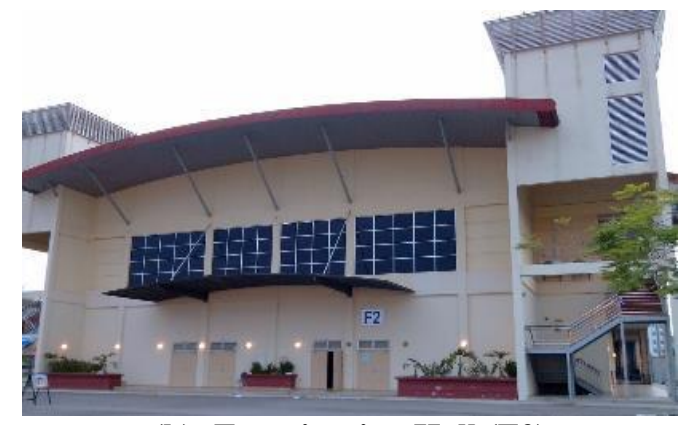

(b) Examination Hall (F2)

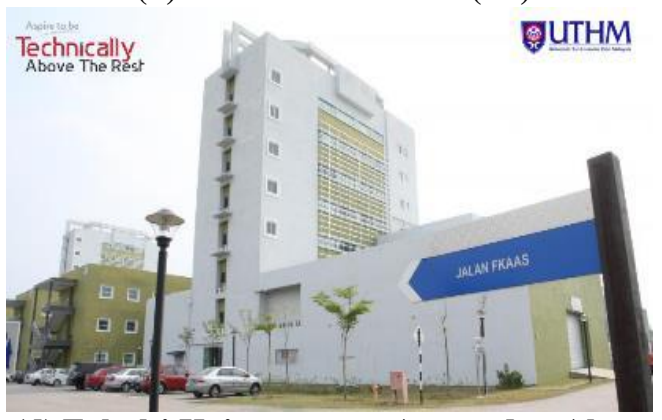

(d) Fakulti Kejuruteraan Awam dan Alam Bina (FKAAB)

(e)

Fig. 5 - The selected buildings

\subsection{Building Rooftop Area Measurement}

The rooftop of Dewan Sultan Ibrahim (DSI), Examination Hall (F2), library, and Fakulti Kejuruteraan Awam dan Alam Bina (FKAAB) are being measured and calculated using Helioscope Software as shown in Fig. 6 and Table 2.
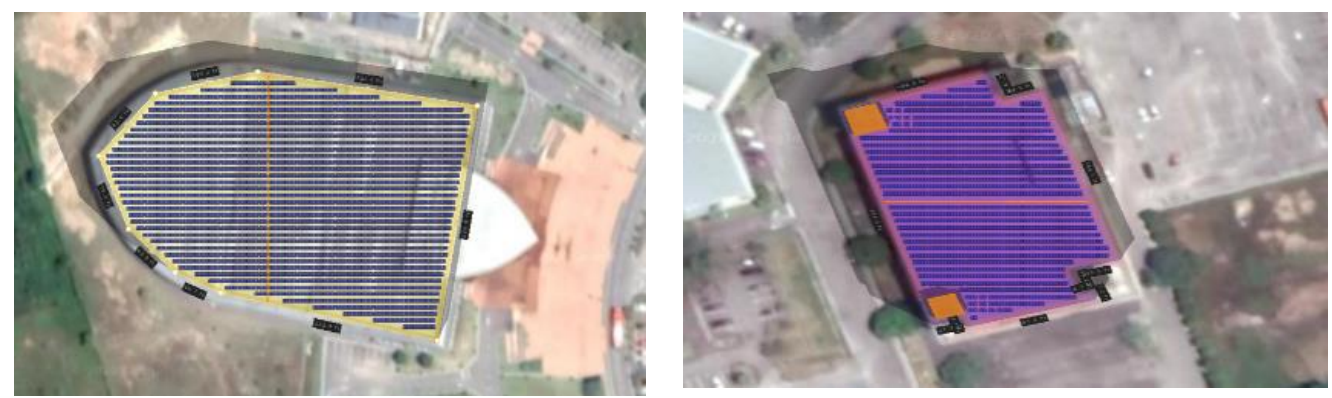

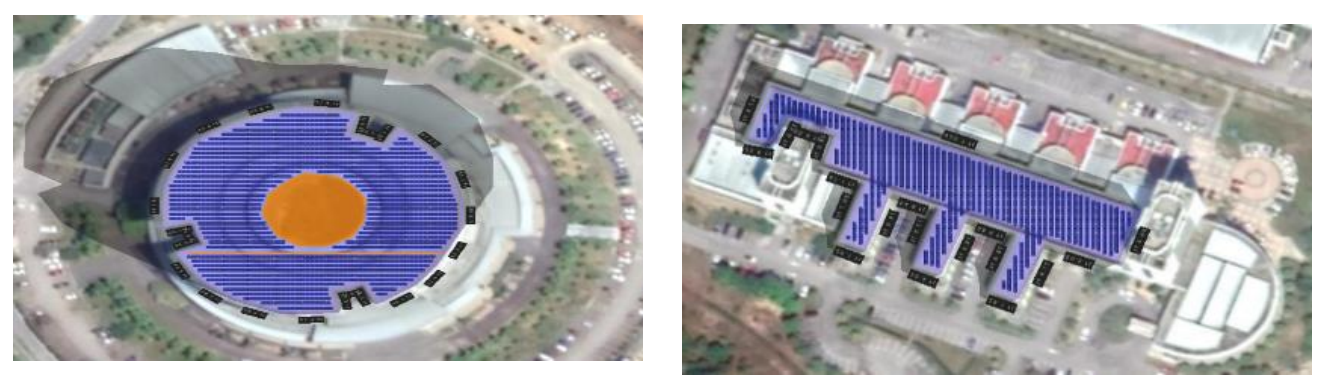

Fig. 6 - Building rooftop area measurement using software

Table 2 - Rooftop area of selected buildings

\begin{tabular}{lc}
\hline Building & Rooftop Area $\left(\mathrm{ft}^{2}\right)$ \\
\hline Dewan Sultan Ibrahim (DSI) & $72,328.6$ \\
Examination Hall (F2) & $28,976.6$ \\
Library, UTHM & $56,357.5$ \\
Fakulti Kejuruteraan Awam dan Alam Bina (FKAAB) & $32,640.2$ \\
Total & $\mathbf{1 9 0 , 3 0 2 . 9}$ \\
\hline
\end{tabular}

Three types of PV modules are considered to evaluate the performance of the proposed GCPV system which are Mono-Si (JKMS360 - 360W), Poly-Si (JKM349P - 340 W), and Thin-Film (FS-6390A - 390 W). The details of PV modules specifications are presented in Appendix A. Based on the rooftop surface area obtained through Helioscope, it could provide the number of PV modules required for the installation as shown in Table 3.

Table 3 - Number of PV modules for different types of panel

\begin{tabular}{lccc}
\hline & \multicolumn{3}{c}{ Type of modules (unit) } \\
\cline { 2 - 4 } Building & $\begin{array}{c}\text { Mono-Si } \\
\text { Jinko Solar } \\
\text { (JKMS36) }\end{array}$ & $\begin{array}{c}\text { Poly-Si } \\
\text { Jinko Solar } \\
\text { (JKM340P) }\end{array}$ & $\begin{array}{c}\text { Thin Film } \\
\text { First Solar } \\
\text { (FS- } \\
\mathbf{6 3 9 0 A})\end{array}$ \\
\hline DSI & 2510 & 2504 & 1977 \\
F2 & 868 & 868 & 683 \\
Library & 1619 & 1619 & 1266 \\
FKAAB & 1027 & 1027 & 807 \\
Total & $\mathbf{6 0 2 4}$ & $\mathbf{6 0 1 8}$ & $\mathbf{4 7 3 3}$ \\
\hline
\end{tabular}

\subsection{Technical Analysis}

The annual energy production is calculated based on a few factors such as the nameplate, output after mismatch, optimal DC output, inverter output and losses. Fig. 7 shows the annual energy production for each building associated with the different types of modules. The total annual energy produced by mono-si, poly-si and thin-film PV modules are $2,332,327.40 \mathrm{kWh}, 2,182,727.90 \mathrm{kWh}$ and 2,066,755.40 $\mathrm{kWh}$ respectively. 


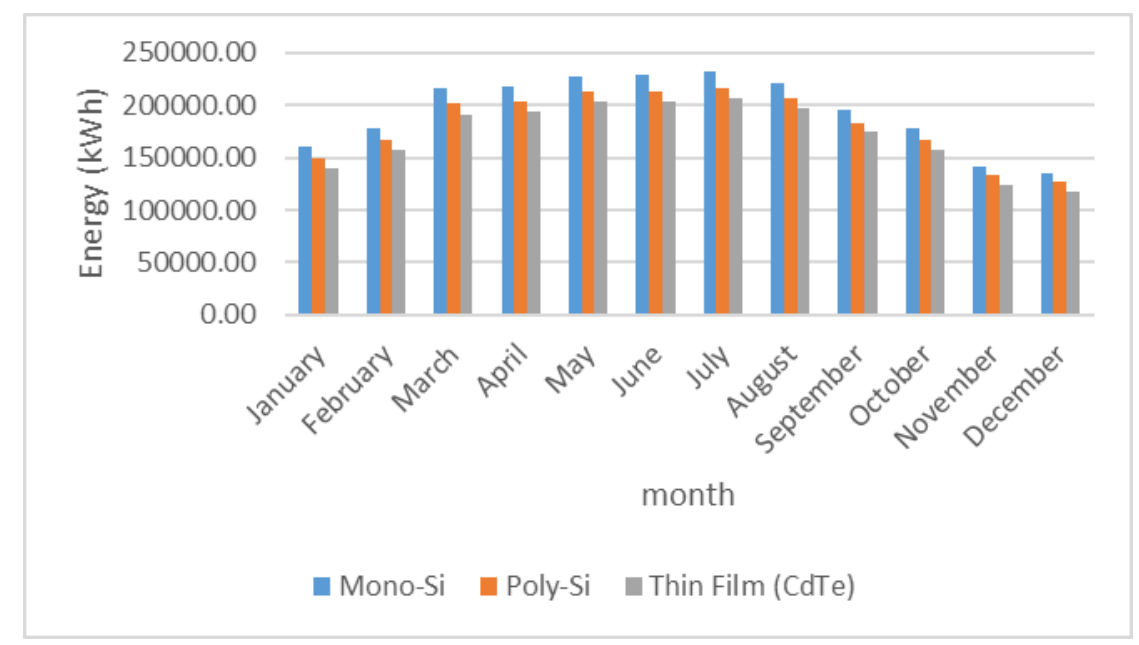

Fig. 7 - Monthly energy production for all selected locations

The Helioscope Software is used to calculate the PR value for the installation of each PV at Dewan Sultan Ibrahim (DSI), Examination Hall (F2), library, and Fakulti Kejuruteraan Awam dan Alam Bina (FKAAB) to determine the net energy output and the nameplate DC power. Fig. 8 shows the performance ratio of PV system with different PV modules for four selected building. It can be seen that the PR of PV system with different PV modules are varies according to location of the building. The Mono-Si produced highest PR for the F2 building. However, the average PR obtained by Mono-Si, Poly-Si and Thin-Film PV module for these buildings is $74.03 \%, 73.73 \%$ and $73.70 \%$, respectively. From these values, it shows that Mono-Si modules can produce slightly better PR than other modules in this case due to its efficiency as shown in the datasheet in Appendix A.

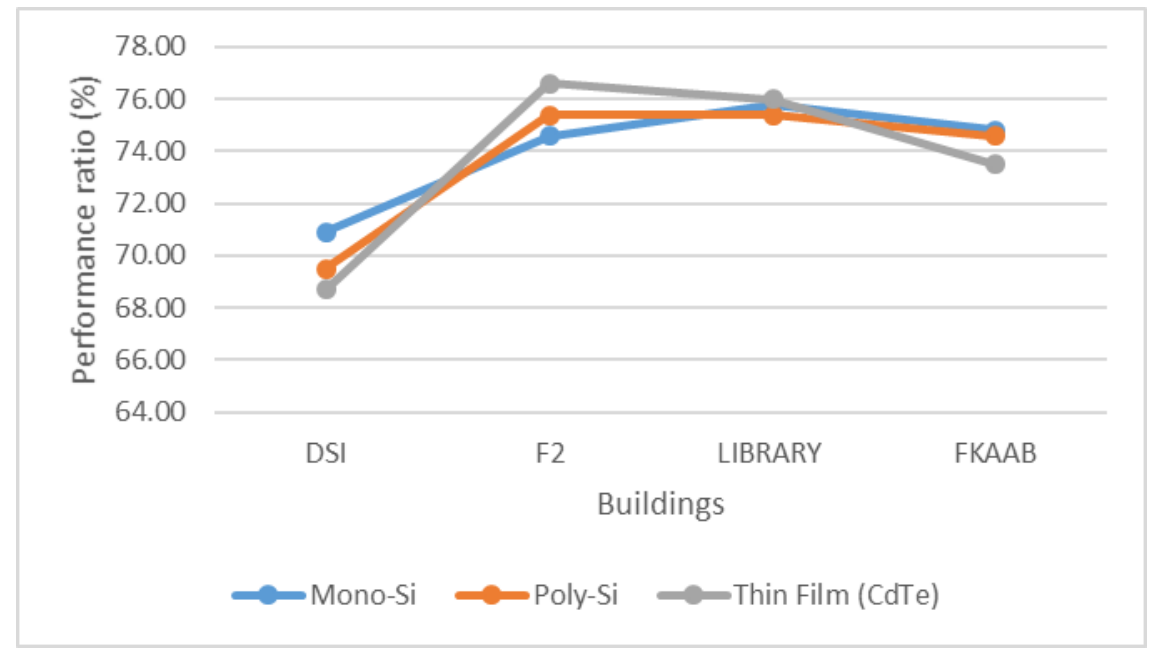

Fig. 8 - Performance ratio of PV system with different PV modules for selected loacation

Specific yield refers to how much energy (kWh) can be produced annually to the installed capacity $(\mathrm{kWp})$ over a typical or actual year. Besides, It is driven by many factors including location, weather, orientation, module selection, and balance of system efficiency. Table 4 shows the breakdown of specific yield for each selected buildings which respect to those of PV modules.

Table 4 - The specific yield $(\mathrm{kWh} / \mathrm{kWp})$ of the different PV modules

\begin{tabular}{lcccc}
\hline Module & DSI & F2 & Library & FKAAB \\
\hline Mono-Si & 1038.20 & 1091.40 & 1108.80 & 1095.00 \\
Poly-Si & 1016.80 & 1103.80 & 1103.70 & 1092.40 \\
Thin Film (CdTe) & 1060.20 & 1182.20 & 1173.10 & 1134.50 \\
\hline
\end{tabular}


The capacity factor (CF) is simply the percentage of the ratio of energy generated per annum divided by $8760 \mathrm{hrs}$ times by the installed capacity of the PV module. The CF has a direct implication on the cost of electricity production. The capacity factor is calculated in excel as shown in Table 5. It shows that the CF of Thin-Film PV module is higher than other modules.

Table 5 - The capacity factor (CF) obtained by different PV modules

\begin{tabular}{lccc}
\hline Module & Installed capacity (kWp) & Annual energy (kWh) & CF(\%) \\
\hline Mono-Si & 2166.40 & 2332327.40 & $\mathbf{1 2 . 2 9}$ \\
Poly-Si & 2046.20 & 2182727.90 & $\mathbf{1 2 . 1 8}$ \\
Thin Film (CdTe) & 1845.00 & 2066755.40 & $\mathbf{1 2 . 7 9}$
\end{tabular}

\subsection{Economic Analysis}

This section presents the performance of PV system for four different cases including existing system (without PV system), PV system Mono-Si, Poly-Si, and thin-film under net metering scheme. The demand from the utility can be reduced when utilizing the PV systems. It found that PV system with Mono-Si module can produced high energy compared to others. From the table, it can be concluded the energy demand from utility can be reduced by Mono-Si, Poly-Si and Thin-Film are $8.7 \%, 8.2 \%$, and $7.7 \%$ respectively as compared to the existing system without PV as shown in Table 6.

Table 6 - Energy consumption, maximum demand, and PV generated energy

\begin{tabular}{lcccc}
\hline Parameters & Without PV System & Mono-Si & Poly-Si & Thin film \\
\hline Energy Generated by Utility (kWh) & $26,682,640$ & $24,350,312.60$ & $24,499,912.10$ & $24,615,884.60$ \\
Energy Supplied by PV (kWh) & 0 & $2,332,327.40$ & $2,182,727.90$ & $2,066,755.40$ \\
\hline
\end{tabular}

The input for RETScreen software is dependent on the output generated by Helioscope. The economic and emission analysis value are generated by RETScreen after obtaining the result for the total area of the rooftop and the number of required PV modules through the helioscope. The total $\mathrm{CO}_{2}$ emission of the grid system is $41,907.10$ tonnes $\mathrm{CO}_{2}$. The $\mathrm{CO}_{2}$ emission produces based on the total energy consumed from the grid system itself. However, grid systems are indicating higher $\mathrm{CO}_{2}$ emission than those grid-connected PV systems because the total energy purchased from grid systems is higher than the grid-connected PV system produced. Therefore, the combination of grid-connected PV systems and grid systems for reducing the $\mathrm{CO}_{2}$ emission shows in Table 7. It can be seen that Mono-Si can provide significant $\mathrm{CO}_{2}$ reduction kcompared to other.

Table 7 - $\mathrm{CO}_{2}$ Emission reduction of grid connected PV system

\begin{tabular}{ccccc}
\hline System & Grid System without PV & Mono-Si & Poly-Si & Thin Film \\
\hline $\mathbf{C O}_{\mathbf{2}}$ Emission $\left(\mathbf{t C O}_{\mathbf{2}}\right)$ & & $40,055.70$ & $40,186.00$ & $40,427.20$ \\
Difference (tCO & & $1,851.40$ & $1,721.10$ & $1,479.90$ \\
Percentage $(\%)$ & $41,907.10$ & 4.4 & 4.1 & 3.5 \\
\hline
\end{tabular}

Besides, the initial costs of the grid-connected PV system have been calculated using RETScreen software for Mono-Si, Poly-Si and thin-film are RM 3,903,552.00, RM 3,686,742.00, and RM 3,327,156.00 respectively as shown in Figure 9. However, the initial cost was still dependent on different components that greatly have been affected the price. This includes the amount of electricity that is needed to offset, and the sun or solar source in the specific area.

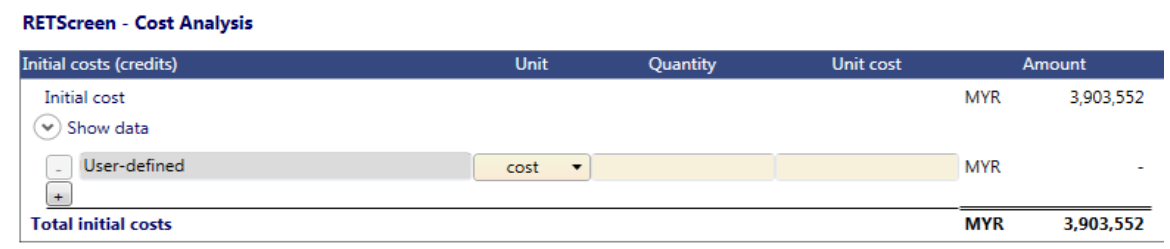

(a) 


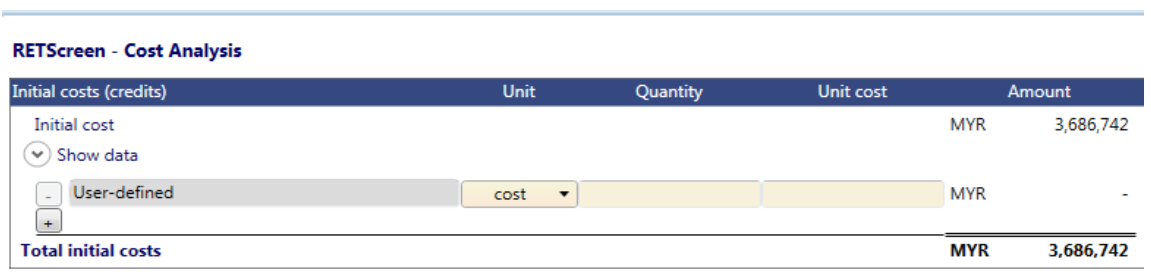

(b)

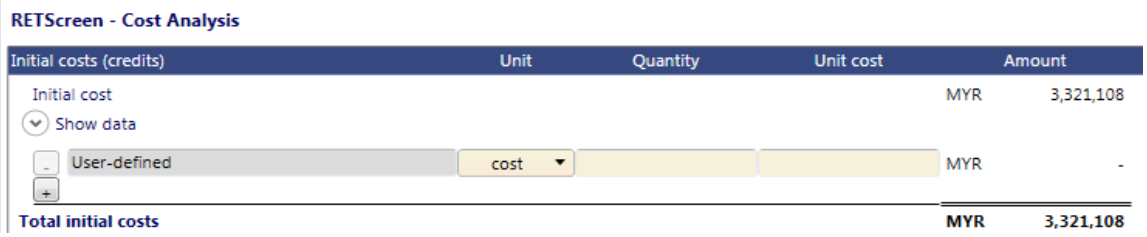

(c)

Fig. 9 - Estimated initial costs for the PV systems; (a) Mono-Si PV System, (b) Poly-Si PV System, and (a) ThinFilm PV System

The study period is set for 21 years based on the NEM contract period in Malaysia to compare the annually saving and payback period for those PV systems. The total bill, net metering saving, payback period, and total profit/saving after the payback period summarized in Table 8. It can be seen that propose PV system with Mono-Si modules can provide high annual saving, less payback period and high profit as compared to others. The Mono-Si PV system can reduced the total lelectricity bill up to $3.6 \%$ compared to the system without the PV system.

Table 8 - Summary of the bill, savings, PBP, and profit after PBP

\begin{tabular}{ccccc}
\hline Parameter & Without PV system & Mono-Si & Poly-Si & Thin-film \\
\hline Total Bill (RM) & $11,832,140.02$ & $11,410,578.09$ & $11,467482,04$ & $11,514,946.25$ \\
Annually Saving (RM) & 0 & $421,561.93$ & $364,657.98$ & $317,193.79$ \\
Payback Period (yr) & 0 & 9.3 & 10.1 & 10.5 \\
Profit after PBP (RM) & 0 & $4,932,274.58$ & $3,974,771.98$ & $3,330,534.90$ \\
\hline
\end{tabular}

\section{Conclusion}

The main objective of this project is to reduce the annual electricity consumption and electricity bill of UTHM with Net Energy Metering (NEM) scheme. From the analysis, it found the Mono-Si and Thin-film were getting fair performance by looking at four aspects which are performance ratio, annual energy production, specific yield, and capacity factor technically. The Mono-Si PV system emerged as the best PV module in terms of performance ratio and annual energy production which are $74.03 \%$ and 2,332,327.40 $\mathrm{kWh}$ respectively. However, the thin-film modules PV system outperforms in terms of specific yield and capacity factor which are $4550 \mathrm{kWh} / \mathrm{kWp}$ and $12.79 \%$ respectively. Likewise for technical performance, there are 4 aspects of the economic components which are Net PV generated energy, carbon dioxide emission reduction, payback period, and profit/saving after payback period have been simulated and supported by RETScreen and Microsoft excel. The Mono-Si was being monopolized of all economic aspects compared to the other two systems which are 2,332,327.40 kWh of Net PV generated energy, $4.4 \% \mathrm{CO}_{2}$ reduction, 9.3 years of payback period considering 21 years of the contractual period. Moreover, the expected profit of Mono-Si is RM4,932,274.58 for 11.7 years after the payback period. From the simulation results, it can be concluded that the Mono-Si is the best PV module for the selected location and capable to reduce the electricity bill and emission of $\mathrm{RM} 421,561.93$ and $1,851.40 \mathrm{tCO}_{2}$ per year respectively.

\section{Acknowledgement}

This research was supported by Ministry of Higher Education, Malaysia through Fundamental Research Grant Scheme (FRGS/1/2018/TK04/UTHM/02/17). The authors would also like to thank the Faculty of Electrical and Electronic Engineering, and Development and Maintenance Office, Universiti Tun Hussein Onn Malaysia for its support.

\section{Appendix A: Technical Specifications of the PV Modules}

Technical Specifications of the PV Modules

\begin{tabular}{lccc}
\hline \multicolumn{1}{c}{ PV Module Technology / Parameters } & Mono-Si & Poly-Si & Thin-Film(CdTe) \\
\hline Manufacturer & Jinkosolar & Jinkosolar & First solar \\
Model & JKMS360 & JKM340P & FS-6390A \\
\hline
\end{tabular}




\begin{tabular}{lccc}
\hline Nominal power, $P_{M P}\left(W_{p}\right)$ & 360 & 350 & 390 \\
Open-circuit voltage, $V_{O C}(\mathrm{~V})$ & 48 & 48 & 214.8 \\
Short-circuit current, $I_{S C}(\mathrm{~A})$ & 9.51 & 9.36 & 2.49 \\
Voltage at point of maximum Power, $V_{M P P}(\mathrm{~V})$ & 39.5 & 38.6 & 173.9 \\
Current at point of maximum Power, $I_{M P P}(\mathrm{~A})$ & 9.12 & 9.07 & 2.24 \\
Module efficiency, $\eta_{m}(\%)$ & 18.6 & 18.07 & 15.8 \\
Reference Temperature, $T_{R e f}\left({ }^{\circ} \mathrm{C}\right)$ & 25 & 25 & 25 \\
Temperature coefficient, $\alpha\left(\mathrm{mA} /{ }^{\circ} \mathrm{C}\right)$ & 4.7 & 5.6 & 0.32 \\
Module Area, $A\left(m^{2}\right)$ & 1.94 & 1.952 & 2.47 \\
\hline
\end{tabular}

\section{References}

[1] R. Górnowicz \& R. Castro. (2020). Optimal design and economic analysis of a PV system operating under Net Metering or Feed-In-Tariff support mechanisms: A case study in Poland. Sustainable Energy Technologies and Assessments, 42, 100863

[2] A. Pino, F. J. P. Lucena, \& J. G. MacHo. (2019). Economic Analysis for Solar Energy Integration in a Microbrewery. SEST 2019 - 2nd Int. Conf. Smart Energy Syst. Technologies. Porto, Portugal

[3] S. Z. Islam, M. L. Othman, M. Saufi, R. Omar, A. Toudeshki, \& S. Z. Islam. (2020). Photovoltaic modules evaluation and dry-season energy yield prediction model for NEM in Malaysia. PLoS One, 15, 1-25

[4] M. A. H. Mohammed. (2018). Potential of Photovoltaic Generation in Universiti Tun Hussein Onn Malaysia. Univ. Tun Hussien Onn Malaysia

[5] M. Obeng, S. Gyamfi, N. S. Derkyi, A. T. Kabo-bah, \& F. Peprah. (2020). Technical and economic feasibility of a $50 \mathrm{MW}$ grid-connected solar PV at UENR Nsoatre Campus. J. Clean. Prod., 247, 119159

[6] A. S. Aziz, M. F. N. Tajuddin, M. R. Adzman, M. F. Mohammed, \& M. A. M. Ramli. (2019). Feasibility analysis of grid-connected and islanded operation of a solar PV microgrid system: A case study of Iraq. Proceedings of ICE-Energy, 191

[7] A. C. Duman \& Ö. Güler. (2019). Economic analysis of grid-connected residential rooftop PV systems in Turkey. Renewable Energy, 148, 697-711

[8] R. H. G. Tan \& T. L. Chow. (2016). A Comparative Study of Feed in Tariff and Net Metering for UCSI University North Wing Campus with 100 kW Solar Photovoltaic System. Energy Procedia, 100, 86-91

[9] Z. G. Piao, B. I. Jung, Y. O. Choi, \& G. B. Cho. (2009). Performance assessment of 3kW grid-connected PV systems in Korea. INTELEC, Int. Telecommun. Energy Conf. Incheon, South Korea

[10] [Online]. Available: https://www.uthm.edu.my/en/

[11] [Online]. Available: https://power.larc.nasa.gov/

[12] F. Ahmadi, N. Khalifa, T. Khir, \& A. Ben Brahim. (2017). Performance analysis of two grid connected PV technologies in climatic operating conditions of South West of Tunisia. Int. Conf. Green Energy Convers. Syst. GECS 2017. Hammamet, Tunisia

[13] R. R. Nagar \& D. L. Gidwani. (2018). Levelized cost of electricity with degradation of 10 MW grid-connected photovoltaic power plant in Kalwakurthy, India. 3rd Int. Conf. Innov. Appl. Comput. Intell. Power, Energy Control. with their Impact Humanit. CIPECH 2018, 50-55. Ghaziabad, India

[14] A. Deo \& G. N. Tiwari. (2014). Performance analysis of $1.8 \mathrm{kWp}$ rooftop photovoltaic system in India. 2014 2nd Int. Conf. Green Energy Technol. ICGET 2014, 87-90. Dhaka, Bangladesh

[15] S. Singh, R. Kumar, \& V. Vijay. (2015). Performance monitoring of $43 \mathrm{~kW}$ thin-film grid-connected roof-top solar PV system. India Int. Conf. Power Electron. IICPE, 2015-May. Kurukshetra, India

[16] A. Arya, M. W. Ahmad, \& S. Anan. (2015). Online monitoring of power extraction efficiency for minimizing payback period of solar PV system. Proc. IEEE Int. Conf. Ind. Technol., 2015-June, 2863-2868. Seville, Spain.

[17] Energy Commission (Malaysia). (2019). Performance and Statistical Information on Electricity Supply Industry in Malaysia 2017. Suruhanjaya Tenaga (Energy Comm.), 1-150

[18] Suruhanjaya Tenaga. 2019. Guidelines For Solar Photovoltaic Installation on Net Energy Metering Scheme. J. Chem. Inf. Model., 8

[19] M. Hayat, F. Shahnia, A. Arefi, H. Iu, \& T. Fernando. 2017. Comparison of the economic benefits and the payback periods of rooftop solar panels in Australia. 3rd Int. Conf. Power Gener. Syst. Renew. Energy Technol. PGSRET 2017, 2018-January, 113-117. Johor Bahru, Malaysia 